\title{
DIVULGING POWER OF WORDS - PERSONAL PRONOUNS AND SPEECH ACTS IN POLITICAL SPEECHES
}

\author{
Hossein Alinezhad ${ }^{1}$, Majid Nemati ${ }^{2}$ \\ ${ }^{1}$ Young Researchers and Elites Club, North Tehran Branch, Islamic Azad University, Tehran, Iran \\ E-Mail: H.alinezhad@ut.ac.ir \\ ${ }^{2}$ University of Tehran, Department of English Language and Literature \\ E-Mail: Nematim@ut.ac.ir
}

\begin{abstract}
Language forms an inseparable part of everyday life. Among its several uses, its role in politics is not negligible. If not the most, politicians are ranked among professional users of language. Through this, they not only communicate, but also persuade people, evoke emotions, and pave the way for their own success and superiority of their parties. To achieve this goal, men of politics use various linguistic and pragmatic properties of language. Personal pronouns, as a linguistic tool which possess an important pragmatic function, are of utmost interest to politicians. In fact, they utilise personal pronouns dexterously and frequently. Contrary to the simplicity of syntactic use, the pragmatics of personal pronouns is not always easy to grasp. Therefore, in order to be fully comprehended, they must be scrutinised in the context of use. This is of vital importance in the political sphere. The present research aimed at investigating the differences in the use of the first personal pronouns (FPPs) and their concurrence with the different types of speech acts. To this end, the researchers analysed 24 speeches by the United Nations representatives of China, the UAE, the UK, and the USA, which were addressed to the United Nations General Assembly (UNGA) from 2012 to 2017. The results revealed that among five classes of the FPPs, "Exclusive We" (982 samples), and "I As an Individual" (7 samples) were the most and the least frequently used ones. In addition, "Commissives" with 818 samples and "Declartives" with 120 samples held the first and the last rank among the speech act types utilised by the four politicians. Finally, the concurrence of "Exclusive We" with" Commissives" was the highest one among all other samples.
\end{abstract}

Key words: personal pronouns, first personal pronouns, speech acts, political speech

\section{INTRODUCTION}

In accordance with the development of human society, language changes and develops. Moreover, there is no doubt language, as a means of communication, is closely related to individuals and their social needs. Consequently, it is not surprising that nearly all of the aspects of our life are affected by language and its use. One of these aspects, which is a great concern in everyday life, is politics. Logically, people consider politicians as dexterous speakers. In fact, politics and language are social stances. While the former includes ideas and activities used to attain and exert authority in society, the 
later paves the way for communication and cohabitation. Therefore, any linguistic study of political language must embrace the social constituents of the both stances. As Van Dijk (2004) wrote, political discourse (discourse as utilised in the political sphere) is a field of linguistic study which is identifiable through its overall systems (democracy, dictatorship), specific social macro actions (like government, legislation, elections, or decision making), micro practices, interactions or discourses (for instance parliamentary debates, and demonstrations), special social relations (such as those of institutional power), special norms or values (e.g. freedom, equality, etc.), and political cognitions (for example political ideologies).

\subsection{Political discourse}

The political discourse exclusively concentrates on the political domination or misuse and reproduction of political power. The fact that political actions are performed through language proves the indestructible relation between these two phenomena. As Chilton (2004) stated, language is the only tool which enables a person to issue orders and threats, inquire, make promises and offers, declare war, state guilty or not guilty, and raise or lower taxes. Therefore, without language, political activity hardly exists. In other words, 'doing' of politics is largely the 'doing' of language (Chilton, 2004).

Politicians are completely aware of the innate ability of language in carrying out political action and encouraging people to attain specific set of goals. Having this point in their minds, men of politics do their best to use this invaluable tool to engineer people's minds and behaviour towards their benefit. This discourse, or language, sums up the world view, perception and vision of the people that create it. Moreover, its intended perlocutionary effect is to persuade and mobilize people to act upon these views. As Durant and Lambrou (2009) mentioned, if the audience believe in speaker's fairness and honesty (i.e. the personal character of the speaker), the emotion aroused by what is said, and evidences provided by the words, they will be persuaded. In a similar vein, Atkinson (1984) believed that a rhetorical discourse must be inclusive and interactive; hence, language and content are of considerable importance to effective communication. Accordingly, Lukes (2005) raised the following question:

Is it not the supreme and most insidious exercise of power to prevent people, to whatever degree, from having grievances by shaping their perceptions, cognitions and preferences in such a way that they accept their role in the existing order of things, either because they see it as natural and interchangeable, or because they value it as divinely ordained or beneficial? (p. 28)

In addition, Jones and Peccei (2004), wrote that in order to secure power, you must convince people that what you want is also good for them. Through this, any leader or ruler can save money on armed forces and police officers who are instruments of exerting authority over the society. They also believed that to attain the aforementioned goal, authorities' ideology must be established to make the beliefs which they want the society to hold appear to be common sense, logical, indisputable, or simply inevitable. Consequently, people almost never inquire these assumptions. Politicians exploit speech to manufacture consent (Fairclough, 1989) and lift their image while, simultaneously, destroying the image of their enemies. In fact, if one can convince the people to accept your right to act in specific ways, then you can so act (Fairclough, 2001). 
Chilton (2004) considered this process as legitimisation of self and the delegitimisation of the other. The former embraces positive self-representation through self apology, self explanation, self justification, self praise, and self identification as a source of authority, reason, sanity, and vision. It is worth mentioning that here, the self is either an individual or the group with which an individual identifies or wishes to identify. At the other end of the spectrum, delegitimisation is manifested through excluding, marginalizing, negative presentation, and scapegoating of the others. It also includes attacking the moral character, communicative cooperation, rationality and sanity of some individuals or groups as well.

As Allen (2007) wrote, the construction of identity, group membership and ways of talking about self, others, and the polarizing categories of us and them forms the most fundamental part of the political sphere. Moreover, appropriate selection of personal pronouns assists politicians to evoke multiple identities of themselves and others from a range of perspectives. He also mentioned that 'it is in the politicians' interest to present themselves as multi-faceted in order to appeal to a diverse audience, and a careful pronoun choice is one way of achieving this aim" (p. 3). Therefore, the most important reason for analyzing pronouns in political discourse is that they help in reconstructing a raft of associations, identities, and ideological groupings.

\subsection{Personal pronouns and speech acts in political speech}

Speakers or writers frequently use pronouns, a group of words which mainly replace nouns, to avoid repetition of the same words. There are different types of pronouns: relative, interrogative, demonstrative, reciprocal, indefinite, possessive, reflexive, and personal (Collins, 1990). Speakers and writers utilise the last type of pronouns to refer to

things or people that they are talking to or about. Moreover, the same type can be used to refer to the speaker/writer him/herself. Personal pronouns are classified into subjective and objective types. The former, roles as subject complement or a subject of a clause/sentence. The latter acts as the object, prepositional complement, or subject complement of a clause.

Traditionally, pronouns have just been analysed deictically and/or anaphorically, which is not helpful in unravelling the associations they politically and socially engender. Accordingly, Pennycook (1994) mentioned that applied linguistics has often chosen a dull descriptivism which presumes the existence of an unproblematic world. This world is clearly referenced through words of a language (for instance pronouns) that are in fact very complex politically and raise difficulty about who is being represented. In addition, Fairclough (1989) believed that English pronouns have relational values, which means values that serve a useful function in construction of social relationships. According to Wodak (2005), pronouns - especially personal plurals - can be employed to persuade people to form the concepts of group identity, coalitions, parties, insiders, and outsiders. Similarly, Bramley (2001) rejected the traditional grammarians' view of pronouns as merely a way of expressing person, number and gender. Instead, he argued that we must consider pronouns in terms of the context of interaction and identity work that they are intended to accomplish. It is in this context that we find this analysis of personal pronouns crucial (i.e., the ability of the analysis to possibly map out pronominal representations carried out in view of political exigencies to serve political goals that may otherwise, under other theoretical constructs, remain opaque). These prove the importance of the analysis of personal pronouns. This includes moving from theory to practice (i.e., careful consideration of pronominal representation in the political sphere to fulfil the related demands). 
According to Bramley (2001), contrary to the third person pronouns, "I" is not used as a substitute for a noun or name, but is a self-reference term. Similarly, Saks (1992) wrote that "I" is a maker of the speakers referring to him/herself, not a substitute for his/her name. In addition, Malone (1997) believed that "I" not only indexes the speaker but also provides personal commitment, subjectivity, and an opportunity to state his/herself. Also, as Beard (2000) asserted, "I" among other personal pronouns displays a sense of personal involvement which is extremely useful in delivering good news.

In addition to its common use, the first subjective personal pronoun "I" has got several functions. To begin with, the speakers use "I" to convey their opinions. Bramely (2001) believed that this shows the speaker's authority, makes the speech more subjective, and can be considered as a way to express sympathy with the audience. Therefore, the subjectivity concern has convinced some politicians to shun using "I" (Pennycook, 1994). Another function of "I" is providing a sense of here and now. In other words, it captures the moment of speaking or writing. In addition, due to its potential to make speech seem more personal (compared to formal neutral ones), "I" creates a relationship with the audience. Last but not least, "I" shows the speaker's or writer's personal involvement in issues, commitment to the audience, and provides him/her with a voice that distances him/her from the others (for example other members of the political party) (Bramely, 2001).

Moreover, Beard (2000) mentioned the advantage and disadvantage of using "I". As he wrote, the advantage of using "I" is that it confirms speaker's/writer's personal involvement. This is obviously visible in the process of delivering positive news. On the other hand, the audience might gather speaker's/writer's frequent use of "I" as an attempt to place him/herself above or outside the shared responsibility of his/her colleagues. Another disadvantage is that using "I" paves the way to easily blame the culprit when something goes wrong (even though he/she is not completely responsible for the deficiency).

Politicians take advantage of the pronoun "I" mainly to accentuate their personal qualities, depict themselves in an effective way, and to come over as good and responsible. Principled, moralist, powerful, and a brave decision maker are among the most common personal qualities that politicians want to express (Bramely, 2001).

It is not easy to comprehend the pragmatic aspects of personal pronouns. As an instance, the pronoun "I" clearly expresses the speaker's or writer's personal opinion, but this is not the case with "you" and "we". While the former can be used to speak for others, the latter may be utilised to distance yourself from someone's else idea.

Similar to "I", "we" is also frequently used in political speeches. Speakers use "we" to express institutional identity. Pennycook (1994) considered "we" as a personal pronoun that simultaneously possesses the opposing qualities of inclusion (i.e. solidarity) and exclusion (i.e. rejection). Interestingly, any construction of "we" assumes the existence of "you" or "they". Therefore, while including, it excludes a parallel "other" which exists elsewhere. Also, Fairclough (1989) wrote that when a leader uses "we" inclusively as a section of a led, it assimilates him/her to the people. This can possibly be an effective humbling technique. Here, a person speaks on behalf of or as a representative of an institution or a group of people. In addition, "we" separates "us" from "them". Druszak (2010) used the term "othering" for this process and considered it as a discursive strategy oriented to manage interpersonal, especially group-based relations by implying or articulating opposite valuations of the self (in-group) and the other (out-group). In fact, by contrasting the pronouns us and them, we are claiming that they are different and perhaps inferior in some way to us, which entails distancing oneself from them. According to Bramely (2001), this 
separation helps the speaker to create a positive image of their own group (political, social, economical, etc.), and simultaneously, project a negative image of the rivals. He later added that the speaker's aim is to include or exclude the audience from group membership, and set one group apart from the other and its activities. Moreover, "we" projects a political party as a team which guarantees a shared responsibility. Put it in another way, the plural pronoun forms (especially "we") provide the audience with a sense of collectivity and help to share responsibility. This is more obvious in making unpopular and doubtful, decisions. In fact, Beard (2000) considered sharing the responsibility as the main advantage of using the pronoun "we" in political speeches. However, it is possible that the others who are included or drawn into the issue of sharing responsibility might not benefit from or agree with it. Interestingly, the latter use of "we" makes the self smaller, by making it a part of a collective. The main function of "we" in political speeches is to create a group where many people are involved, instead of referring to one particular individual (Bramley, 2001).

One important area of language (particularly in pragmatics) is of speech acts. They are communicative acts that convey an intended language function. Speech acts include functions such as requests, apologies, suggestions, commands, offers, and appropriate responses to those acts. Speakers success in message conveyance completely depends on the listener's perception of their intended meaning. Speech acts occur in everyday talk in every society, with various ranges of explicitness. For second language learners, it is important to know which speech acts are different in the first and target language, how they are different, and what is not appropriate to say. Politicians are not exceptions in this case and do their best to persuade people about their merit and tarnish public image of their rivals. Therefore, speech acts play an important role in the political speech.

According to speech act theory (Austin, 1962; Searle, 1969), the performance of a speech act involves the performance of three types of act. Firstly, a locutionary act which is the act of saying. Secondly, an illocutionary act which means the performance of a particular language function by what is said. Thirdly, a perlocutionary act which equals to the achievement of some kind of effect on the adressee. Levinson (as cited in Ellis, 2007) wrote that speech act is generally used to refer exclusively to illocutionary act. Searle (1975) classified speech acts into five general classes of representatives (i.e. which commit the speaker to the truth of the expressed proposition), directives (i.e. which are attempts by the speaker to get the addressee to do something), commissives (i.e. which commit the speaker to some future course of action), expressives (i.e. which express a psychological state), and declarations (i.e. which effect immediate changes in the

institutional state of affairs and which tend to rely on elaborate extra-linguistic institutions). The following table includes examples of each category.

Table 1 Examples of Searle 's (1975) five general classes of speech acts

\begin{tabular}{|l|l|}
\hline Speech Acts & Example \\
\hline Representatives & asserting, concluding \\
Directives & requesting, ordering, questioning \\
Commissives & promising, threatening, offering \\
Expressives & thanking, congratulating, apologizing, welcoming \\
Declarations & excommunicating, declaring war, marrying, firing \\
\hline
\end{tabular}




\section{PURPOSE OF THE STUDY}

As it was previously mentioned pronouns are important part of speech. Richards and Schmidt (2002) defined personal pronouns as the set of pronouns which represent the grammatical category of the person and which in English is made up of "I", "you", "he", "she", "it", "we", "you", "they", and their derived forms (me, mine, yours, him, his, hers.etc). In addition to their main function - work as a substitute for nouns and noun phrases - pronouns possess pragmatic functions too. Who are the politicians referring to when they use personal pronouns like "I" and "we" in their utterances? It is not always easy to define what referential source is intended to when it comes to interpersonal pronouns. According to Connor and Upton (2004), interpersonal pronouns are first and second personal pronouns in both the plural and the singular which are used to express interpersonal interaction and personal involvement but also what they call politeness strategies with a purpose to show belonging of any kind. As Halliday (2000) wrote, personal system, including pronouns and possessives, can be employed to realize interpersonal meaning of language. There are three categories of personal pronouns. The first category includes "I" and "we". The second one includes "you" (singular and plural). The third includes "they" and "it". In political speech, the interpersonal meaning exists in the communication between the speaker and the audience. When one is giving an address, the purpose of it is to inform, suggest and communicate. Selecting different personal pronouns affects the audience in multiple ways, because the choice of personal pronoun can clearly make the audience know the attitude of the speaker. It can reflect the social relationship between the speaker and audience too.

Generally speaking, first personal pronoun includes singular form "I" and the plural form "we". The first personal pronoun "I" represents the speaker himself/herself, and the speaker often adopts "I" to state his/her own personal views and feelings. "We" means a group of people including the speaker and/or writer. Similarly, in political sphere, "we" refers to the speaker and all the audience together. The frequent use of "we" in political speech has the effect of making the audience feel that the speaker is on the side of the audience. In order to win the support from the audience, speakers often use "we" to indicate that they are closely related to the audience.

Another important area of language (particularly in pragmatics) is of speech acts. They are communicative acts that convey an intended language function. Fasold and Connor-Linton (2006) defined speech act as an action performed by one person using language. It can be labelled by a noun that names the act. The speaker intends to communicate the act and that intention is recognised by the recipient. Speech acts form a vital part of any piece of language, and are a matter of utmost importance in political settings. In Speech Act analysis, for example, the preference of one act over another may prove an ideological preference. Such analysis also emphasizes the positioning of the addresser and not that of the addressee and how the latter's mental resources may be used to presuppose ideological realities. Speech acts include functions such as requests, apologies, suggestions, commands, offers, and appropriate responses to those acts. Speakers success in message conveyance completely depends on the listener's perception of their intended meaning. Speech acts occur in everyday talk in every society, with various ranges of explicitness. For second language learners, it is important to know which speech acts are different in the first and target language, how they are different, and what is not appropriate to say. Politicians are not exceptions in this case. As it was previously mentioned, they do their best to persuade people about their merit and tarnish public image of their rivals. Therefore, speech acts play an important role in the political speech. 
This study compared and analyzed the use of first personal pronouns (FPPs) in the speeches held by American president, the British prime minister, the president of China, and minister of foreign affairs of the United Arab Emirates in the United Nations General Assembly (UNGA). Due to the similarity of speech setting, factors which can potentially affect the quality of speech (audience, length, etc.) were controlled. Moreover, the researchers did not focus on the single political system and covered the most widespread ones (Federal, Republic, Constitutional monarchy, and Absolute monarchy). It is worth mentioning that the aforementioned countries possessed different cultures too. These points paved the way for objective an unbiased selection and analysis of the speeches. The FPPs which were analysed include "I" and "we". They were chosen because they are the most interesting ones in political contexts, and the ones that affect the outcome of the speeches by either including or excluding the audience. In addition, the present study investigated the frequency of use of the FPPs among the personal pronouns (PPs), and type of speech acts which accompanied them. The latter was done by concentrating on the verbs which followed "I" and "we".

In order to fulfill the purpose of the study, the following research questions were formulated:

1. What is the frequency of use of the FPPs in the four politicians' speeches?

2. What is the frequency of use of different types of the FPPs in the four politicians' speeches?

3. What types of speech acts do four politicians use in their speeches?

4. What is the frequency of use of different types of speech acts in the four politicians' speeches?

5. What is the concurrence of different types of the FPPs and different types of speech acts?

\section{MATERIALS AND METHODS}

At the outset of the study, the researchers collected 24 speeches of the previously mentioned politicians addressed to UNGA from 2012 to 2017. Once the speeches were collected, they were analysed based on two criteria; the FPPs and speech acts.

The first criterion (the FPPs) included:

1. The number and percentage of "I" and "we" in speakers' speeches among all types of PPs

2. The number and percentage of different types of "I" and "we" in speeches

The following table shows the different types of first personal pronoun in this research.

Table 2 Classification of FPPs

\begin{tabular}{|l|l|}
\hline FPP & Type \\
\hline I & $\begin{array}{l}\text { As an individual (member of a nation, etc.) } \\
\text { As an authority (president, prime minister, king, etc.) }\end{array}$ \\
\hline We & $\begin{array}{l}\text { Inclusive (speaker + audience) } \\
\text { Exclusive (speaker + they*) } \\
\text { Interchangeable (instead of I ) } \\
* \text { they refers to government, parliament, companies, banks, heads } \\
\text { of the tribes, religious leaders and other similar authorities in the } \\
\text { country or political system }\end{array}$ \\
\hline
\end{tabular}


In order to utilise the second criterion (i.e. speech acts), the researchers focused on the verbs which followed or associated with the FPPs "I" and "we". As the next step, he categorised them based on the Searle's (1975) classifications of speech acts (Table 1.) Then, the number and percentage of use for each type of speech acts was calculated. In order to answer the last research question, the researchers worked out the percentage of concurrence for each type of the FPPs and related classes of speech acts. Consequently, the results are divided into various sections. The first one presents number and percentage of different categories of first personal pronouns in speeches. The second one embraces the number and percentage of the speech acts performed by verbs which follow or associate with the aforementioned pronouns. The third part includes the concurrence percentage of first personal pronouns and speech act classes.

\section{RESULTS}

To answer the first question of the study which concerned the frequency of use of the FPPs, the researchers counted all examples of PPs. Then, the proportion of the FPPs was calculated. The following table summarises the findings.

Table 3 Number and Proportion of PP and FPP

\begin{tabular}{|l|c|c|c|}
\hline Country & Number of PP & Number of FPP & Proportion of FPP \\
\hline China & 416 & 373 & $89.66 \%$ \\
The UAE & 290 & 279 & $96.20 \%$ \\
The UK & 521 & 410 & $78.69 \%$ \\
The USA & 1098 & 816 & $74.31 \%$ \\
\hline Total & 2325 & 1878 & $80.77 \%$ \\
\hline
\end{tabular}

To address the second question of the research, the classification of the FPPs (represented in Table.1) was utilised. Table 4 shows the number of different types of "I" in all lectures. Here, "IAI" and "IAA" represent "I As an Individual" and "I As an Authority" respectively.

Table 4 Frequency of Different Types PP "I" in Politicians' Speeches

\begin{tabular}{|c|c|c|c|c|c|c|c|}
\hline Country & 2012 & 2013 & 2014 & 2015 & 2016 & 2017 & Total \\
\hline China & $\begin{aligned} \mathrm{IAI} & =0 \\
\mathrm{IAA} & =3\end{aligned}$ & $\begin{aligned} \mathrm{IAI} & =0 \\
\mathrm{IAA} & =3\end{aligned}$ & $\begin{array}{c}\mathrm{IAI}=0 \\
\mathrm{IAA}=0\end{array}$ & $\begin{aligned} \mathrm{IAI} & =0 \\
\mathrm{IAA} & =3\end{aligned}$ & $\begin{array}{c}\mathrm{IAI}=1 \\
\mathrm{IAA}=4\end{array}$ & $\begin{array}{c}\mathrm{IAI}=0 \\
\mathrm{IAA}=0\end{array}$ & $\begin{array}{c}\mathrm{IAI}=1 \\
\mathrm{IAA}=13\end{array}$ \\
\hline The UAE & $\begin{array}{r}\mathrm{IAI}=0 \\
\mathrm{IAA}=5\end{array}$ & $\begin{aligned} \mathrm{IAI} & =1 \\
\mathrm{IAA} & =8\end{aligned}$ & $\begin{aligned} \mathrm{IAI} & =0 \\
\mathrm{IAA} & =7\end{aligned}$ & $\begin{aligned} \mathrm{IAI} & =0 \\
\mathrm{IAA} & =2\end{aligned}$ & $\begin{aligned} \mathrm{IAI} & =0 \\
\mathrm{IAA} & =7\end{aligned}$ & $\begin{array}{r}\mathrm{IAI}=0 \\
\mathrm{IAA}=2\end{array}$ & $\begin{aligned} \mathrm{IAI} & =1 \\
\mathrm{IAA} & =31\end{aligned}$ \\
\hline The UK & $\begin{aligned} \mathrm{IAI} & =4 \\
\mathrm{IAA} & =14\end{aligned}$ & $\begin{array}{c}\mathrm{IAI}=0 \\
\mathrm{IAA}=8\end{array}$ & $\begin{array}{c}\mathrm{IAI}=0 \\
\mathrm{IAA}=7\end{array}$ & $\begin{array}{r}\mathrm{IAI}=0 \\
\mathrm{IAA}=3\end{array}$ & $\begin{array}{c}\mathrm{IAI}=0 \\
\mathrm{IAA}=8\end{array}$ & $\begin{aligned} \mathrm{IAI} & =0 \\
\mathrm{IAA} & =21\end{aligned}$ & $\begin{aligned} \mathrm{IAI} & =4 \\
\mathrm{IAA} & =61\end{aligned}$ \\
\hline The USA & $\begin{aligned} \text { IAI } & =0 \\
\text { IAA } & =17\end{aligned}$ & $\begin{aligned} \mathrm{IAI} & =0 \\
\mathrm{IAA} & =42\end{aligned}$ & $\begin{aligned} \mathrm{IAI} & =0 \\
\mathrm{IAA} & =15\end{aligned}$ & $\begin{aligned} \mathrm{IAI} & =0 \\
\mathrm{IAA} & =30\end{aligned}$ & $\begin{aligned} \mathrm{IAI} & =1 \\
\mathrm{IAA} & =60\end{aligned}$ & $\begin{aligned} \mathrm{IAI} & =0 \\
\mathrm{IAA} & =16\end{aligned}$ & $\begin{array}{c}\mathrm{IAI}=1 \\
\mathrm{IAA}=164\end{array}$ \\
\hline Total & $\begin{aligned} \text { IAI } & =4 \\
\mathrm{IAA} & =39\end{aligned}$ & $\begin{aligned} \text { IAI } & =1 \\
\mathrm{IAA} & =61\end{aligned}$ & $\begin{aligned} \mathrm{IAI} & =0 \\
\mathrm{IAA} & =29\end{aligned}$ & $\begin{aligned} \mathrm{IAI} & =0 \\
\mathrm{IAA} & =38\end{aligned}$ & $\begin{aligned} \mathrm{IAI} & =2 \\
\mathrm{IAA} & =79\end{aligned}$ & $\begin{aligned} \mathrm{IAI} & =0 \\
\mathrm{IAA} & =39\end{aligned}$ & $\begin{array}{c}\mathrm{IAI}=7 \\
\mathrm{IAA}=285\end{array}$ \\
\hline
\end{tabular}


In addition, the same classification was used to categorise different types of PPs "we" in politicians' speeches. It is worth mentioning that no example of the "Interchangeable We" was found in all lectures. Consequently, this class is not mentioned in the tables. In the following table, "INW" and "EXW" refer to "Inclusive We" and "Exclusive We" respectively.

Table 5 Frequency of Different Types PP "We" in Politicians' Speeches

\begin{tabular}{|l|c|c|c|c|c|c|c|}
\hline Country & 2012 & 2013 & 2014 & 2015 & 2016 & 2017 & Total \\
\hline China & $\mathrm{INW}=34$ & $\mathrm{INW}=2$ & $\mathrm{INW}=21$ & $\mathrm{INW}=23$ & $\mathrm{INW}=9$ & $\mathrm{INW}=14$ & $\mathrm{INW}=103$ \\
& $\mathrm{EXW}=60$ & $\mathrm{EXW}=87$ & $\mathrm{EXW}=7$ & $\mathrm{EXW}=21$ & $\mathrm{EXW}=60$ & $\mathrm{EXW}=21$ & $\mathrm{EXW}=256$ \\
\hline The UAE & $\mathrm{INW}=0$ & $\mathrm{INW}=0$ & $\mathrm{INW}=8$ & $\mathrm{INW}=1$ & $\mathrm{INW}=3$ & $\mathrm{INW}=15$ & $\mathrm{INW}=27$ \\
& $\mathrm{EXW}=38$ & $\mathrm{EXW}=33$ & $\mathrm{EXW}=55$ & $\mathrm{EXW}=36$ & $\mathrm{EXW}=21$ & $\mathrm{EXW}=37$ & $\mathrm{EXW}=220$ \\
\hline \multirow{2}{*}{ The UK } & $\mathrm{INW}=14$ & $\mathrm{INW}=17$ & $\mathrm{INW}=36$ & $\mathrm{INW}=16$ & $\mathrm{INW}=79$ & $\mathrm{INW}=57$ & $\mathrm{INW}=219$ \\
& $\mathrm{EXW}=15$ & $\mathrm{EXW}=50$ & $\mathrm{EXW}=15$ & $\mathrm{EXW}=17$ & $\mathrm{EXW}=17$ & $\mathrm{EXW}=12$ & $\mathrm{EXW}=126$ \\
\hline The USA & $\mathrm{INW}=25$ & $\mathrm{INW}=20$ & $\mathrm{INW}=43$ & $\mathrm{INW}=51$ & $\mathrm{INW}=79$ & $\mathrm{INW}=37$ & $\mathrm{INW}=255$ \\
& $\mathrm{EXW}=49$ & $\mathrm{EXW}=94$ & $\mathrm{EXW}=77$ & $\mathrm{EXW}=53$ & $\mathrm{EXW}=28$ & $\mathrm{EXW}=79$ & $\mathrm{EXW}=380$ \\
\hline \multirow{2}{*}{ Total } & $\mathrm{INW}=73$ & $\mathrm{INW}=39$ & $\mathrm{INW}=108$ & $\mathrm{INW}=91$ & $\mathrm{INW}=170$ & $\mathrm{INW}=123$ & $\mathrm{INW}=604$ \\
& $\mathrm{EXW}=162$ & $\mathrm{EXW}=264$ & $\mathrm{EXW}=154$ & $\mathrm{EXW}=127$ & $\mathrm{EXW}=126$ & $\mathrm{EXW}=149$ & $\mathrm{EXW}=982$ \\
\hline
\end{tabular}

Table 6 represents the frequency and percentage of the types of the FPPs in all of the speeches.

Table 6 Overall Frequency and Percentage of the Types of the FPPs

\begin{tabular}{|l|c|r|}
\hline FPP Type & Frequency & Percent \\
\hline IAI & 7 & 0.37 \\
IAA & 285 & 15.18 \\
INW & 604 & 32.16 \\
EXW & 982 & 52.29 \\
\hline Total & 1878 & 100.0 \\
\hline
\end{tabular}

After analysing all of the 24 speeches, the researchers found that all types of the speech acts were used by the politicians. Next table shows the frequency of the use of different types of the speech acts for 4 countries from 2012 to 2017. 
Table 7 Frequency of the Types of Speech Acts

\begin{tabular}{|l|r|r|r|r|r|r|r|}
\hline Type of Speech Act & 2012 & 2013 & 2014 & 2015 & 2016 & 2017 & Total \\
\hline China & & & & & & & \\
Assertives & 21 & 19 & 4 & 7 & 23 & 11 & 85 \\
Directives & 4 & 7 & 6 & 5 & 2 & 3 & 27 \\
Commissives & 57 & 50 & 13 & 25 & 41 & 16 & 203 \\
Expressives & 15 & 13 & 5 & 6 & 8 & 5 & 52 \\
Declaratives & 0 & 3 & 0 & 3 & 0 & 0 & 6 \\
\hline The UAE & & & & & & & \\
Assertives & 4 & 4 & 6 & 6 & 8 & 5 & 33 \\
Directives & 5 & 4 & 6 & 2 & 0 & 1 & 18 \\
Commissives & 6 & 13 & 20 & 11 & 7 & 31 & 88 \\
Expressives & 16 & 14 & 21 & 8 & 9 & 9 & 77 \\
Declaratives & 12 & 7 & 17 & 12 & 7 & 8 & 63 \\
\hline The UK & & & & & & & \\
Assertives & 10 & 18 & 11 & 5 & 33 & 15 & 92 \\
Directives & 3 & 4 & 13 & 1 & 33 & 19 & 73 \\
Commissives & 12 & 30 & 20 & 23 & 29 & 31 & 145 \\
Expressives & 19 & 20 & 10 & 7 & 8 & 21 & 85 \\
Declaratives & 3 & 3 & 4 & 0 & 1 & 4 & 15 \\
\hline The USA & & & & & & & \\
Assertives & 21 & 44 & 28 & 25 & 23 & 27 & 168 \\
Directives & 0 & 2 & 2 & 1 & 4 & 17 & 26 \\
Commissives & 36 & 60 & 83 & 67 & 82 & 54 & 382 \\
Expressives & 24 & 42 & 15 & 36 & 56 & 31 & 204 \\
Declaratives & 10 & 8 & 7 & 3 & 3 & 3 & 36 \\
\hline Total & & & & & & & \\
Assertives & 56 & 85 & 49 & 43 & 87 & 58 & 378 \\
Directives & 12 & 27 & 9 & 39 & 40 & 144 \\
Commissives & 15 & 136 & 126 & 160 & 132 & 818 \\
Expressives & 21 & 28 & 20 & 11 & 66 & 418 \\
Declaratives & & & & & & & 120 \\
\hline
\end{tabular}

Table 8 shows the frequency and percentage of the types of speech acts in all 24 lectures.

Table 8 Overall Frequency and Percentage of the Types of Speech Acts

\begin{tabular}{|l|c|r|}
\hline Speech Act Type & Frequency & Percent \\
\hline Assertives & 378 & 20.13 \\
Directives & 144 & 7.67 \\
Commissives & 818 & 43.55 \\
Expressives & 418 & 22.25 \\
Declaratives & 120 & 6.40 \\
\hline Total & 1878 & 100.00 \\
\hline
\end{tabular}

In order to calculate the concurrence of different types of the FPPs and different types of speech acts, crosstab tests were used. The following table represents the frequency of the concurrence of different types of the FPPs and different types of speech acts in politicians' speeches from 2012 to 2017. 
Table 9 Frequency of Concurrence of Different Types of FPP and Types of Speech Acts

\begin{tabular}{|c|c|c|c|c|c|}
\hline \multirow[t]{2}{*}{ Type of Speech Act } & Types & of & First & Personal & Pronoun \\
\hline & IAI & IAA & INW & EXW & Total \\
\hline \multicolumn{6}{|l|}{ China } \\
\hline Assertives & 0 & 1 & 14 & 70 & 85 \\
\hline Directives & 0 & 0 & 13 & 14 & 27 \\
\hline Commissives & 0 & 0 & 62 & 141 & 203 \\
\hline Expressives & 1 & 7 & 14 & 30 & 52 \\
\hline Declaratives & 0 & 5 & 10 & 1 & 6 \\
\hline \multicolumn{6}{|l|}{ The UAE } \\
\hline Assertives & 0 & 2 & 4 & 27 & 33 \\
\hline Directives & 0 & 0 & 0 & 18 & 18 \\
\hline Commissives & 1 & 2 & 16 & 69 & 88 \\
\hline Expressives & 0 & 17 & 4 & 56 & 77 \\
\hline Declaratives & 0 & 10 & 3 & 50 & 63 \\
\hline \multicolumn{6}{|l|}{ The UK } \\
\hline Assertives & 1 & 7 & 57 & 27 & 92 \\
\hline Directives & 0 & 7 & 60 & 6 & 73 \\
\hline Commissives & 0 & 6 & 72 & 67 & 145 \\
\hline Expressives & 3 & 24 & 27 & 21 & 85 \\
\hline Declaratives & 0 & 7 & 3 & 5 & 15 \\
\hline \multicolumn{6}{|l|}{ The USA } \\
\hline Assertives & 0 & 23 & 58 & 87 & 168 \\
\hline Directives & 0 & 3 & 16 & 7 & 26 \\
\hline Commissives & 1 & 39 & 135 & 207 & 382 \\
\hline Expressives & 0 & 100 & 34 & 70 & 204 \\
\hline Declaratives & 0 & 15 & 12 & 80 & 36 \\
\hline \multicolumn{6}{|l|}{ Total } \\
\hline Assertives & 1 & 33 & 133 & 211 & 378 \\
\hline Directives & 0 & 10 & 89 & 45 & 144 \\
\hline Commissives & 2 & 47 & 285 & 484 & 818 \\
\hline Expressives & 4 & 158 & 79 & 177 & 418 \\
\hline Declaratives & 0 & 37 & 18 & 65 & 120 \\
\hline
\end{tabular}

Table 10 shows the percentage of the concurrence of types of speech acts and the FPPs in all 24 lectures.

Table 10 Overall Percentage of Concurrence of Different Types of FPP and Types of Speech Acts

\begin{tabular}{|l|l|l|l|l|l|}
\hline \multirow{2}{*}{ Type of Speech Act } & \multicolumn{4}{|c|}{ Type of FPP } & Total \\
\cline { 2 - 5 } & IAI & IAA & INW & EXW & \\
\hline Assertives & 0.26 & 8.73 & 35.19 & 55.82 & 100 \\
Directives & 0 & 6.95 & 61.80 & 31.25 & 100 \\
Commissives & 0.24 & 5.75 & 34.84 & 59.17 & 100 \\
Expressives & 0.95 & 37.80 & 18.90 & 42.35 & 100 \\
Declaratives & 0 & 30.84 & 15 & 54.16 & 100 \\
\hline
\end{tabular}




\section{CONCLUSIONS}

As the findings of the present study revealed PPs are frequently used in the political speeches. In fact, PPs form an inseparable part of this genre. The huge number of PPs (2325 samples) supports this claim. In addition, $80.77 \%$ (1878 samples) of PPs was dominated by the FPPs (I and We). This clearly, proved that politicians are aware of the role that this class of PPs play (i.e. inclusion and exclusion of the others). Among 1878 FPPs, EXW, INW, IAA, and IAI ranked from the top to the bottom of the frequency scale $(982,604,285$, and 7 samples respectively). Considering the types of speech acts, out of 1878 samples, Commissives with 818 samples (43.55\%), Expressives with 418 samples $(22.25 \%)$, Assertives with 378 samples (20.13\%), Directives with 144 samples (7.67\%), and Declaratives with 120 samples $(6.40 \%)$ held the first to the last rank. The highest level of occurrence of the FPPs and types of speech act types belonged to EXW and Commissives with 489 samples, while the lowest one were IAI and Directives, and IAI and Declaratives with 0 samples. The president of the USA used the highest number of PPs and the FPPs with 1098 and 816 samples respectively. The lowest number of PPs (290) and the FPPs (279) were used by the minister of the foreign affairs and international cooperation of the UAE.

The huge number of PPs is an undeniable indicator of their importance in the political discourse. Interestingly, FPPs (I, We) are ranked first among other types of the same category. Among all types of FPPs, no sample of "Interchangeable We" was found. This shows that politicians (at least in the countries that were studied here) are conscious of the negative feeling and hostility aroused by the contemptuous voice of "Interchangeable We". "EXW" and "IAI" are ranked the first and the last in among different types of FPPs respectively. This could be in favour of globalisation process. In other words, this proves that politicians (and people who consider them as role models) are separating from individualism. Moreover, they incline towards collectivism which is in harmony with the contemporary concepts of global village and peaceful coexistence. However, the dominance of "EXW" over "INW" conveys a sort of dilemma. On the one hand, it is a kind of "We" and shows the shift of axis from individualism (I) toward collectivism (We). On the other hand, it simultaneously conveys the concept of self-assurance (in contrast with believing in and trusting others). To put it in another way, politicians (at least those who were studied here and in UNGA context) still count on their own nation, government, party, resources, and etc. instead of the potential of the global community.

Considering the speech acts, it is worth mentioning that all types of Searle's (1975) classification were used in the present sample. However, the frequency of use and the concurrence with FPPs are of utmost importance.

Having the frequency of the use of the speech act types in the mind, Commissives (43.55\%) and Declaratives (6.40\%) held the most and the least rank. In addition, Directives (7.67\%) is the force one on the same scale. These show that in the contemporary world, there is no or little room for dictatorial authorities. In other words, politicians are completely aware of the significance of considering different nations and people as the building blocks of the global community. Therefore, in order to achieve development and other beneficent goals, men of politics need people's company and support. Logically, these are not achieved by pressure or intimidation, but through peaceful process of wisdom of the crowd. Commissives are the best way to achieve these aims. In fact, through utilisation of Commissives, heads of states show their respect for people. Consequently, authorities and people work together to achieve the desired goals. In such circumstances, there is no room 
for ordering people (directive) or using your authority to inaugurate acts which are not supported by the majority (for example wars, deprivation of citizenship or civil rights, etc.) through declarative function.

Focusing on the concurrence of speech act type and FPPs reveals that there is no example of "IAI and Directives" and "IAI and Declaratives". This is obviously in harmony with what has been mentioned previously. It clearly shows that absolutely no one has the right and is able to lead and decide for the world. 489 samples of concurrence between "EXW and Commissives" form another line of support for this reality too. Maybe, it would be wise to claim that the time of "charisma" and "one-man show" passed. The world is pleading for equality, respect, and peace.

Like all researches, the present investigation faced limitations which imposed inevitable restrictions on the interpretations and generalisations of the outcome. To begin with, it is a well-known reality that leading politicians receive help with the writing of their speeches. Logically, it can be assumed that all speeches are produced with the help of professional speechwriters. Therefore, the researchers did not know how much the four politicians actually wrote for themselves and how much they were helped with, and how much the amount of help varied between them. Then, the length and topics of the speeches will not be the same which will make the quantitative analysis unequal. This is observable in the related percentages of the FPPs. Also, the native language of two politicians was not English and, the researchers had access to English translations. Consequently, the researchers potentially missed some pronouns and speech acts due to the differences between languages. Last but not least, researchers limited the study to the FPPs and their different types.

In order to avoid the subjectivity and biased analysis, four countries with Federal, Republic, Constitutional monarchy, and Absolute monarchy systems and distinctive cultures were selected. These types of government, represent the dominant political systems in the contemporary world. Also, the number of FPPs and Speech Acts and their concurrence were analysed. In other words, the researchers neither focused on the political content of the speeches nor concentrated on the speakers' personal qualities. Therefore, these factors did not affect the selection and analysis of the speech samples.

Last but not least, due to the equality of factors like time, audience, and even the place of speeches, UNGA was selected.

The results of the present study can be used as a cultural tool in evaluating the political speeches. Also, they might be helpful in discovering the ideologies behind the words. In addition, the results could be useful for educating and providing appropriate materials for students of political science, journalism, world studies, sociology, and media mainly in their ESP courses. Finally, the results have the potential to be used as a part of an introductory course for the crew of the ministry of foreign affairs, future diplomats and ambassadors. Other studies can focus on other forms of PPs (instead of "I" and "we") and gender factor. In fact, enthusiastic researchers can compare male and female politicians' (whether from the same or different countries, political parties, etc.) use of PPs and/or the FPPs with respect to the frequency and concurrence with different types of speech acts. 


\section{REFERENCES}

Allen, W. (2007). Australian political discourse: Pronominal choice in campaign speeches. In I. Mushin \& M. Laughren (Eds.), Annual meeting of the Australian Linguistic Society. Retrieved from http://espace.library.uq.edu.au

Atkinson, J. M. (1984). Our masters' voices: The Language and body language of politics. London: Methuen.

Austin, J. (1962). How to do things with words? Oxford: Clarendon Press.

Beard, A. (2000). Language of Politics. London: Routledge

Bramley, N. R. (2001). Pronouns of Politics: The use of pronouns in the construction of 'self' and 'other' in political interviews. Retrieved from digitalcollections.anu.edu.au

Chilton, P. (2004). Analysing political discourse: Theory and practice. London: Routledge.

Collins, C. (1990). English grammar. London: Collins ELT

Connor, U., \& Upton, A.T. (Eds.). (2004). Discourse in the professions. John Benjamins Publishing Company: Amsterdam.

Druszak, A. (2010). Re-reading the communist past in Poland: The dynamics of us and them. In A. Druszak, J. House, L. Kumiega (Eds.), Globalization, discourse, media: In a critical perspective (pp.191-209). Warsaw: Warsaw University Press.

Durant, A. \& Lambrou, M. (2009). Language and media: A resource book for students. London and New York: Routledge.

Ellis, R. (2007). The study of second language (2nd ed.). Oxford: Oxford University Press.

Fairclough, N. (1989). Language and power. Harlow: Longman.

Fairclough, N. (2001). Language and power (2nd ed.). Harlow: Pearson Education.

Fasold, R.W. \& Connor-Linton, J. (Eds.). (2006). An introduction to language and linguistics. Cambridge: Cambridge University Press.

Halliday, M. A. K. (2000). An Introduction to functional grammar (2nd ed.). Beijing: Foreign Language Teaching and Research Press.

Jones, J. \& Peccei, J. S. (2004). Language and politics. In L. Thomas (Ed.), Language, society, and power. New York: Routledge.

Levinson, S. (1983). Principles of pragmatics. Cambridge: Cambridge University Press.

Lukes, S. (2005). Power: A radical view (2nd ed.). New York: Palgrave MacMillan.

Malone, M.J. (1997). Worlds of talk: The presentation of self in everyday conversation. Oxford: Polity Press.

Pennycook, A. (1994). The politics of pronouns. ELT Journal, 48(2):173-8.

Richards, C. J. \& Schmidt, R. (2002). Dictionary of language teaching \& applied linguistics. London: Longman

Sacks, H. (1992). Lectures on conversations. Oxford: Blackwell.

Searle, J. (1969). Speech acts. Cambridge: Cambridge University Press.

Searle, J. (1975). Indirect speech acts. In P. Cole and J. Morgan (Eds.): Syntax and semantics 3: Speech Acts. New York: Academic Press.

Van Dijk, T. A. (2004). Politics, ideology and discourse. In R. Wodak, (Ed.), Encyclopaedia of language and linguistics.

Wodak, R. (2005). A new agenda in critical discourse analysis theory, methodology and interdisciplinarity. Philadelphia: John Benjamins Publishing Company. 